\title{
CHANGES IN ATHLETIC FITNESS OF JUNIOR SPORTS DANCERS DURING A TEN-MONTH TRAINING CYCLE
}

\author{
Aistė Barbora Ušpurienė, Algirdas Čepulėnas \\ Lithuanian Academy of Physical Education, Kaunas, Lithuania
}

\begin{abstract}
Research background and hypothesis. Research shows that the mastery level of dancers in sports dancing is closely related to their athletic fitness though there has not been enough research in the changes of indices of athletic fitness of junior sports dancers while training sports dancing. The present study aims at verifying the hypothesis that training in sports dancing should improve athletic fitness of sports dancers.

Research aim was to test the effect of training in sports dancing on the indices of athletic fitness of junior sports dancers.

Research methods. The subjects in the research were 14 junior sports dancers: 7 girls and 7 boys. The dancers were tested twice: in January 2010 and in November 2010. The training sessions were held three times a week. We established the following indices of athletic fitness: hand grip strength, the frequency of fine hand movements, the frequency of leg movement running on the spot for $10 \mathrm{~s}$, speed of hand movements performing 25 cycles of movements, static balance, trunk flexibility, dynamic strength endurance of abdominal muscles, explosive strength and speed strength of legs, explosive strength endurance, simple and complex psychomotor reaction to light stimulus.

Research results. Dancing practice sessions had a positive effect on psychomotor abilities of boys and girls simple psychomotor reaction for girls $(\mathrm{p}<0.05)$ and simple and complex psychomotor reaction for boys $(\mathrm{p}<0.05)$. The indices of athletic fitness of junior sports dancers did not change much in the research period.

Discussion and conclusions. Specialized dancing practice sessions did not have significant effect on the improvement of athletic fitness, however, a tendency of improvement in athletic fitness was observed. Athletic fitness is a significant component of junior sports dancers' sports fitness, and the improvement of athletic fitness indices requires inclusion of athletic training into the programs of training sports dancers, or regular practice sessions in sports dancing should be supplemented with physical exercises for the development of motor skills.
\end{abstract}

Keywords: sports dances, athletic training, motor skills, dancing practice sessions, training.

\section{INTRODUCTION}

$\mathrm{S}$ ports dances arouse much interest among scientists and experts as motor activity combining elements of sport and art expression (Haight, 1998; Карпенко, Сивицкий, 2009). The process of athlete training is oriented to sports results and is associated with the realization of physical abilities in the development of mastership, emotional satisfaction in dancing, the development of artistic abilities to express the idea of dance in body movements (Kavaliauskas, 2004; Рубштейн, 2005; Torrents et al., 2011). In sports dancing contests the pairs are evaluated according to the rhythm and plastic of movements, dancing technique, movement coherence, body posture and hand position, harmony of movements in a pair (Starosta, 2003; Карпенко, Сивицкий, 2009; 
Климова, 2009). Synchronicity of movements, interaction between dancers, repeated sequences of movements, dancers' contacts dancing in a pair are of great importance (Torrents et al., 2011). Sports dancers perform non-standard dynamic movements at shifting intensities (Dornowski, Zabrocka, 2008). During a dance much time is spent performing the workload at the intensities exceeding the anaerobic threshold (Faina, Bria, 2000). The mastership of dancers much depends on their athletic fitness* (Miletić, 1999; Климова, 2009; Радионов, 2011).

Technical fitness of sports dancers is closely related to their motor skills: coordination, speed, flexibility, speed strength and endurance (Fostiak, 1996; Miletić, 1999; Pilewska, 2003; Климова, 2009). In standard and Latin American dancing the dancers need good general and special endurance (Репникова, 2004). The level of motor skills such as explosive strength, flexibility, speed, greatly influences the energy outlay of the human body in Latin American dances (Михайлов, 1999; Пискунова, 2004). The better the strength endurance of dancers, the lower the energy outlay in standard dancing (Репникова, 2004; Хемпшир, 2000). Professional literature highlights teaching and improving dancing technique (The Revised Technique of Latin-American Dancing ISTD, 1983), but little attention is paid to the problems of athletic training. Research sources (Kostić et al., 2003; Климова, 2009) maintain that training 5-7-year-old children, their program should include physical exercises for the development of their motor skills. The problem of athletic training of junior sports dancers has not received adequate attention yet (Терехова, 2007; Радионов, 2011).
We suppose that changes in training and athletic fitness indices of junior sports dancers is a relevant research problem worth studying.

Research aim was to study the impact of training sports dancing on the indices of athletic fitness of junior dancers.

\section{RESEARCH METHODS}

The study was carried out in Jonava city sports dance club "Bonus" the head and the coach of which was Sergei Jefimenka. The subjects were 14 junior dancers -7 boys and 7 girls. The mean age of the girls was $13.00 \pm 1.00$ years, and that of the boys was $13.33 \pm 0.82$ years. According to the age classifier in sports dancing (Age Limitations, 2009 - Amžiaus apribojimai, 2009) the subjects were attributed to junior group according to the mastery level in sports the subjects matched level E4, E6 and D classificatory classes (Regulations of Classificatory Classes, 2009-Kvalifikaciniu klasiu nuostatai, 2009). The height of female dancers was $162.00 \pm 8.14 \mathrm{~cm}$, their body mass was $45.57 \pm 6.97$ $\mathrm{kg}$, their body mass index $-17.31 \pm 1.87 \mathrm{~kg} / \mathrm{m}^{2}$. The boys' height was $164.17 \pm 10.96 \mathrm{~cm}$, body mass $50.33 \pm 11.84 \mathrm{~kg}$, and their body mass index -18.44 $\pm 1.87 \mathrm{~kg} / \mathrm{m}^{2}$. The dancers were tested two times. The first period of testing was January 2010, and the second - November 2010. Organized group training sessions with a coach were held three times a week. The dancers developed their technical, tactical and special fitness according to the coach's plan (Table 1). Besides group training sessions, on the other days the dancers trained individually independently or with a coach (individually paid classes).

Table 1. Annual training plan for junior group dancers

\begin{tabular}{|c|c|c|c|c|c|c|c|c|c|c|c|c|}
\hline Periods & \multicolumn{2}{|c|}{ Preparatory } & \multicolumn{2}{|c|}{ Competition } & \multirow{2}{*}{\begin{tabular}{|c} 
Transition \\
XII
\end{tabular}} & \multicolumn{2}{|c|}{ Preparatory } & \multicolumn{3}{|c|}{ Competition } & \multicolumn{2}{|c|}{ Transition } \\
\hline Months & VIII & IX & $X$ & $\mathrm{XI}$ & & $\mathrm{I}$ & II & III & IV & $\mathrm{V}$ & VI & VII \\
\hline Technical and special training, $\%$ & 70 & 60 & 40 & 40 & 40 & 60 & 60 & 35 & 35 & 35 & 65 & \multirow{4}{*}{ • } \\
\hline Tactical training, $\%$ & 30 & 40 & 60 & 60 & 60 & 40 & 40 & 65 & 65 & 65 & 35 & \\
\hline Competitions & - & + & + & + & - & - & + & + & + & + & - & \\
\hline Number of hours for training a week & 10 & 8 & 7 & 7 & 5 & 8 & 8 & 7 & 7 & 7 & 8 & \\
\hline
\end{tabular}

\footnotetext{
Athletic fitness is the level of training physical abilities and complex skills necessary for the chosen branch of sport and preconditioning good sports results (Dictionary of Sports Terms, 2002 - Sporto terminų žodynas, 2002).
} 
(Skernevičius et al., 2004): running on the spot raising the knees high (when the thigh reaches the horizontal position) for $10 \mathrm{~s}$; Tapping Test $3 \times 10 \mathrm{~s}$; hand movement speed test - the person had to perform 25 movements as fast as possible and to touch circles on a plane which were $60 \mathrm{~cm}$ apart from each other (Eurofit, 1993); Sit and Reach Test for $30 \mathrm{~s}$ (Johnson, Nelson, 1986); standing on the front foot of one leg until the person can keep balance, and the time is recorded; standing vertical jumps taking off with both feet without hand movement with a squat of $90^{\circ}$, and with a squat of $135^{\circ}$ with hand movement.

Leg muscle fatigue and endurance were estimated when the dancers performed a serious of 20 jumps from a squat position at the angle of $90^{\circ}$ (Skurvydas, Mamkus, 1990). Psychomotor reactions were measured applying diagnostic device KTD-8. We measured simple psychomotor reaction time, when the dancers knew exactly what stimulus they had to react to, and complex psychomotor reaction, when there were several stimuli, and the dancers had to react only to one of them. The subjects had to react to light stimuli.
During the group training sessions no physical exercises for athletic fitness and specific motor skills were performed. Two-week micro-cycle models were applied: the model of basic special training (Table 2) and direct training for competitions - precompetition micro-cycle (Table 3). The research methods applied were as follows: literature review, one-alternative natural experiment, motor skill testing.

The research data were processed applying the methods of mathematical statistics (Microsoft Office Excel Programme). We calculated the arithmetic mean $(\bar{x})$, standard deviation $( \pm \mathrm{SD})$, Student $(t)$ test criterion, and index $p$ for statistical significance. The level of significance was set at $95 \%$, when $\mathrm{p}<0.05$.

The body composition indices of dancers were established according to the approved methods (Skernevičius et al., 2004). The hand grip strength was measured with a dynamometer which had to be clenched with maximal effort. Motor abilities (speed, flexibility, balance, strength endurance) were measured using recommended approved tests

Table 2. The model of a weekly micro-cycle of practice sessions for basic special training

\begin{tabular}{|c|c|c|}
\hline Tuesday & Thursday & Friday \\
\hline 10 min warm-up & 10 min warm-up & 10 min warm-up \\
\hline $\begin{array}{c}30 \text { min improvement of the basics of } \\
\text { technique of one standard dance (e. g. } \\
\text { Slow Waltz) one by one and in pairs, } \\
\text { without music (counting) and with } \\
\text { music. }\end{array}$ & $\begin{array}{c}30 \text { min improvement of the basics of } \\
\text { technique of one Latin American dance } \\
\text { (e. g. Rumba) one by one and in pairs, } \\
\text { without music (counting) and with } \\
\text { music. }\end{array}$ & $\begin{array}{c}15 \text { min improvement of choreographies } \\
\text { of standard dances in pairs. }\end{array}$ \\
\hline \multirow[t]{3}{*}{$\begin{array}{l}20 \text { min improvement of the variations } \\
\text { of the same dance dancing in pairs. }\end{array}$} & $\begin{array}{l}20 \text { min improvement of the variations of } \\
\text { the same dance dancing in pairs. }\end{array}$ & $\begin{array}{l}10 \text { min dancing of five dances for } 1 \mathrm{~min} \\
30 \mathrm{~s} \text { with minimal breaks of rest. }\end{array}$ \\
\hline & & $\begin{array}{l}15 \text { min improvement of choreographies } \\
\text { of Latin American dances in pairs. }\end{array}$ \\
\hline & & $\begin{array}{l}10 \text { min dancing of five dances for } 1 \mathrm{~min} \\
30 \mathrm{~s} \text { with minimal breaks of rest. }\end{array}$ \\
\hline
\end{tabular}

Table 3. The model of a weekly micro-cycle of pre-competition practice sessions

\begin{tabular}{|c|c|c|}
\hline Tuesday & Thursday & Friday \\
\hline 10 min warm-up & 10 min warm-up & 10 min warm-up \\
\hline $\begin{array}{c}10 \text { min improvement of Slow Waltz } \\
\text { competitive programme in pairs }\end{array}$ & $\begin{array}{c}10 \text { min improvement of Samba } \\
\text { competitive programme in pairs }\end{array}$ & $\begin{array}{c}15 \text { min improvement of choreographies of } \\
\text { standard dances in pairs. }\end{array}$ \\
\hline $\begin{array}{c}10 \text { min improvement of Tango } \\
\text { competitive programme in pairs }\end{array}$ & $\begin{array}{c}10 \text { min improvement of Cha Cha Cha } \\
\text { Dance competitive programme in pairs }\end{array}$ & $\begin{array}{c}10 \text { min dancing of five dances for } 1 \text { min } \\
30 \mathrm{~s} \text { with minimal breaks of rest. }\end{array}$ \\
\hline $\begin{array}{c}10 \text { min improvement of Vienna Waltz } \\
\text { competitive programme in pairs }\end{array}$ & $\begin{array}{c}10 \text { min improvement of Rumba } \\
\text { competitive programme in pairs }\end{array}$ & $\begin{array}{c}15 \text { min improvement of choreographies of } \\
\text { Latin American dances in pairs. }\end{array}$ \\
\hline $\begin{array}{c}10 \text { min improvement of Quickstep } \\
\text { competitive programme in pairs }\end{array}$ & $\begin{array}{c}10 \text { min improvement of Jive Dance } \\
\text { competitive programme in pairs }\end{array}$ & $\begin{array}{c}10 \text { min dancing of five dances for } 1 \text { min } \\
30 \mathrm{~s} \text { with minimal breaks of rest. }\end{array}$ \\
\hline
\end{tabular}




\section{RESEARCH RESULTS}

Research findings given in Tables 4 and 5 allow estimating the achieved levels of motor skills (speed, flexibility, balance, strength endurance) for speed dancers - boys and girls. The frequency of steps for girls was $40.57 \pm 4.86$ steps during $10 \mathrm{~s}$ in the first study, and that for boys was $47.64 \pm$ 1.51 steps, and in the second study they were at the same level ( $p>0.05)$. The speed of hand movement can be evaluated can be estimated according to the time needed for 25 movement cycles for the

Table 4. Changes in the indices of athletic fitness for junior girls in sports dancing

\begin{tabular}{|c|c|c|c|c|c|c|c|c|c|c|c|c|}
\hline \multirow{2}{*}{ 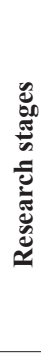 } & \multirow{2}{*}{ 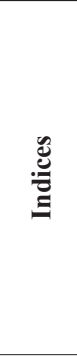 } & \multicolumn{2}{|c|}{$\begin{array}{l}\text { Hand grip } \\
\text { strength, kg }\end{array}$} & \multirow{2}{*}{$\begin{array}{l}\text { Number of } \\
\text { steps while } \\
\text { running } \\
\text { in place } \\
\text { during } \\
10 \mathrm{~s} \text {, times }\end{array}$} & \multicolumn{2}{|c|}{$\begin{array}{c}\text { Hand movement } \\
\text { speed-time } \\
\text { needed for } \\
\text { 25-movement } \\
\text { cycles, } s \\
\end{array}$} & \multirow{2}{*}{$\begin{array}{l}\text { Number } \\
\text { of fine } \\
\text { movements } \\
\text { during } 30 \mathrm{~s} \text { in } \\
\text { tapping test, } \\
\text { times }\end{array}$} & \multirow{2}{*}{$\begin{array}{c}\text { Sit and } \\
\text { lie down } \\
\text { test } \\
\text { during } \\
30 \mathrm{~s}, \\
\text { times }\end{array}$} & \multirow{2}{*}{$\begin{array}{l}\text { Sit and } \\
\text { reach } \\
\text { test, } \\
\mathrm{cm}\end{array}$} & \multicolumn{3}{|c|}{$\begin{array}{l}\text { Vertical jump in place taking } \\
\text { off with both feet, } \mathrm{cm}\end{array}$} \\
\hline & & $\begin{array}{l}\text { Left } \\
\text { hand }\end{array}$ & $\begin{array}{l}\text { Right } \\
\text { hand }\end{array}$ & & $\begin{array}{l}\text { Left } \\
\text { hand }\end{array}$ & $\begin{array}{l}\text { Right } \\
\text { hand }\end{array}$ & & & & $\begin{array}{l}\text { With a } \\
\text { squat } \\
\text { at the } \\
\text { angle } \\
\text { of } 90^{\circ}\end{array}$ & $\begin{array}{l}\text { With a } \\
\text { squat } \\
\text { at the } \\
\text { angle } \\
\text { of } 130^{\circ}\end{array}$ & $\begin{array}{l}\text { With hand } \\
\text { movement }\end{array}$ \\
\hline \multirow{4}{*}{ I } & $\bar{x}$ & 17.00 & 18.43 & 40.57 & 13.44 & 12.61 & 146.43 & 24.43 & 36.57 & 22.49 & 16.36 & 27.07 \\
\hline & $\pm \mathrm{SD}$ & 4.20 & 4.24 & 4.86 & 1.15 & 1.30 & 5.38 & 4.12 & 5.16 & 3.42 & 3.99 & 4.43 \\
\hline & Min & 12.00 & 12.00 & 32.00 & 12.10 & 11.10 & 141.00 & 21.00 & 30.00 & 19.00 & 14.00 & 21.00 \\
\hline & Max & 23.00 & 24.00 & 48.00 & 15.30 & 14.80 & 156.00 & 32.00 & 44.00 & 27.00 & 22.00 & 32.00 \\
\hline \multirow{5}{*}{ II } & $\bar{x}$ & 18.43 & 19.14 & 41.14 & 12.70 & 11.91 & 142.29 & 24.43 & 36.86 & 23.68 & 17.05 & 27.29 \\
\hline & $\pm \mathrm{SD}$ & 4.04 & 3.76 & 5.02 & 1.06 & 1.37 & 9.39 & 4.68 & 4.88 & 3.72 & 3.75 & 4.43 \\
\hline & Min & 13.00 & 15.00 & 32.00 & 11.4 & 10.10 & 12.90 & 21.00 & 31.00 & 20.00 & 15.00 & 21.00 \\
\hline & Max & 25.00 & 24.00 & 48.00 & 14.3 & 14.20 & 156.00 & 32.00 & 44.00 & 29.00 & 23.00 & 32.00 \\
\hline & $\mathrm{p}$ & $>0.05$ & $>0.05$ & $>0.05$ & $>0.05$ & $>0.05$ & $<0.05$ & $>0.05$ & $>0.05$ & $<0.05$ & $<0.05$ & $>0.05$ \\
\hline
\end{tabular}

Table 5. Changes in the indices of athletic fitness for junior boys in sports dancing

\begin{tabular}{|c|c|c|c|c|c|c|c|c|c|c|c|c|}
\hline \multirow{2}{*}{ 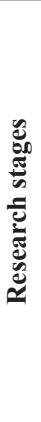 } & \multirow{2}{*}{ 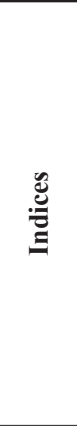 } & \multicolumn{2}{|c|}{$\begin{array}{l}\text { Hand grip } \\
\text { strength, kg }\end{array}$} & \multirow{2}{*}{$\begin{array}{c}\text { Number } \\
\text { of steps } \\
\text { while } \\
\text { running } \\
\text { in place } \\
\text { during } \\
10 \mathrm{~s} \text {, times }\end{array}$} & \multicolumn{2}{|c|}{$\begin{array}{c}\text { Hand } \\
\text { movement } \\
\text { speed-time } \\
\text { needed for } \\
\text { 25-movement } \\
\text { cycles, } s \\
\end{array}$} & \multirow{2}{*}{$\begin{array}{c}\text { Number } \\
\text { of fine } \\
\text { movements } \\
\text { during } 30 \mathrm{~s} \\
\text { in tapping } \\
\text { test, times }\end{array}$} & \multirow{2}{*}{$\begin{array}{c}\text { Sit and } \\
\text { lie down } \\
\text { test } \\
\text { during } \\
30 \mathrm{~s}, \\
\text { times }\end{array}$} & \multirow{2}{*}{$\begin{array}{c}\text { Sit and } \\
\text { reach } \\
\text { test, } \\
\mathrm{cm}\end{array}$} & \multicolumn{3}{|c|}{$\begin{array}{l}\text { Vertical jump in place taking } \\
\text { off with both feet, } \mathrm{cm}\end{array}$} \\
\hline & & $\begin{array}{l}\text { Left } \\
\text { hand }\end{array}$ & $\begin{array}{l}\text { Right } \\
\text { hand }\end{array}$ & & $\begin{array}{l}\text { Left } \\
\text { hand }\end{array}$ & $\begin{array}{l}\text { Right } \\
\text { hand }\end{array}$ & & & & $\begin{array}{l}\text { With a } \\
\text { squat } \\
\text { at the } \\
\text { angle } \\
\text { of } 90^{\circ}\end{array}$ & $\begin{array}{l}\text { With a } \\
\text { squat } \\
\text { at the } \\
\text { angle } \\
\text { of } \\
130^{\circ}\end{array}$ & $\begin{array}{l}\text { With hand } \\
\text { movement }\end{array}$ \\
\hline \multirow{4}{*}{ I } & $\bar{x}$ & 24.00 & 24.50 & 47.67 & 13.13 & 12.47 & 141.83 & 29.50 & 30.50 & 22.45 & 14.48 & 30.14 \\
\hline & $\pm \mathrm{SD}$ & 3.03 & 2.59 & 1.51 & 2.85 & 0.87 & 10.21 & 3.62 & 6.57 & 6.13 & 2.11 & 8.25 \\
\hline & Min & 20.00 & 21.00 & 46.00 & 11.30 & 11.90 & 129.00 & 24.00 & 20.00 & 14.00 & 11.00 & 21.00 \\
\hline & Max & 28.00 & 28.00 & 50.00 & 18.80 & 14.20 & 156.00 & 33.00 & 36.00 & 32.00 & 17.00 & 43.00 \\
\hline \multirow{5}{*}{ II } & $\bar{x}$ & 25.00 & 25.00 & 47.08 & 12.72 & 12.12 & 146.67 & 30.33 & 30.83 & 22.75 & 15.68 & 28.33 \\
\hline & $\pm \mathrm{SD}$ & 2.97 & 2.37 & 1.24 & 2.70 & 1.00 & 5.85 & 3.44 & 5.98 & 6.35 & 2.45 & 9.33 \\
\hline & Min & 21.00 & 22.00 & 45.00 & 11.00 & 11.10 & 140.00 & 25.00 & 21.00 & 15.00 & 12.00 & 17.00 \\
\hline & Max & 29.00 & 28.00 & 48.00 & 18.10 & 14.00 & 156.00 & 33.00 & 36.00 & 32.00 & 19.00 & 43.00 \\
\hline & $\mathrm{p}$ & $>0.05$ & $>0.05$ & $>0.05$ & $\begin{array}{c}> \\
0.05\end{array}$ & $>0.05$ & $<0.05$ & $>0.05$ & $>0.05$ & $>0.05$ & $>0.05$ & $<0.05$ \\
\hline
\end{tabular}


right and the left hands. In the first study the girls performed 25-movement cycles with the right hand in $12.61 \pm 1.30 \mathrm{~s}$, with the left hand - in 13.44 $\pm 1.15 \mathrm{~s}$, for boys those indices were relatively $12.47 \pm 0.87$ and $13.13 \pm 2.85 \mathrm{~s}$. In the second study the indices of hand movement speed for girls and boys were slightly higher, but the changes were not statistically significant ( $p>0.05)$. The number of fine movements of boys (Tapping Test) during $30 \mathrm{~s}$ increased from $141.83 \pm 10.21$ to $146.67 \pm 5.85$ times $(\mathrm{p}<0.05)$, but for girls it decreased $(\mathrm{p}<0.05)$. Both girls and boys achieved the greatest number of fine movements during the first $10 \mathrm{~s}$, and later the frequency of movements gradually decreased (Figure 1, 2).

Flexibility of girls was better than that of boys (Table 4, 5), and in the second study the index of flexibility for girls was $36.86 \pm 4.88 \mathrm{~cm}$, and for boys $-30.83 \pm 5.98(\mathrm{p}<0.05)$. Both girls and boys achieved higher indices of static balance standing on one foot in the third trial in the first and the second studies (Figure 3, 4). The hand-grip strength of the left hand of girls and boys increased during the second study, but the changes were insignificant $(\mathrm{p}>0.05)$.

The indices of the Sit up Lie down Test during $30 \mathrm{~s}$ (Table 4,5) did not change during the whole research $(\mathrm{p}>0.05)$. Dynamic strength endurance of the boys' abdominal muscles was better than that of the girls $(p<0.05)$. The indices of the vertical jumps show the explosive strength of legs (jump from a squat position at the angle of $90^{\circ}$ ) and speed strength (jump from a squat position at the angle of $130^{\circ}$ ). The explosive strength of leg muscles of both boys and girls tended to improve in the course of the study, but the changes were low $(p>0.05)$. The indices of 20 -jump series show that strength endurance of leg muscles in girls and boys slightly improved (Figure 5,6). The average height of jump in a series during the second study was $19.57 \pm 0.50 \mathrm{~cm}$ for girls and $22.57 \pm 0.84 \mathrm{~cm}$ for boys. Simple psychomotor reaction for boys and girls (Table 6) performing the task with the right and the left hands improved $(p<0.05)$. The
Figure 1. Changes in the frequency of hand movements for girls in $30 \mathrm{~s}$
Figure 2. Changes in the frequency of hand movements for boys in $30 \mathrm{~s}$
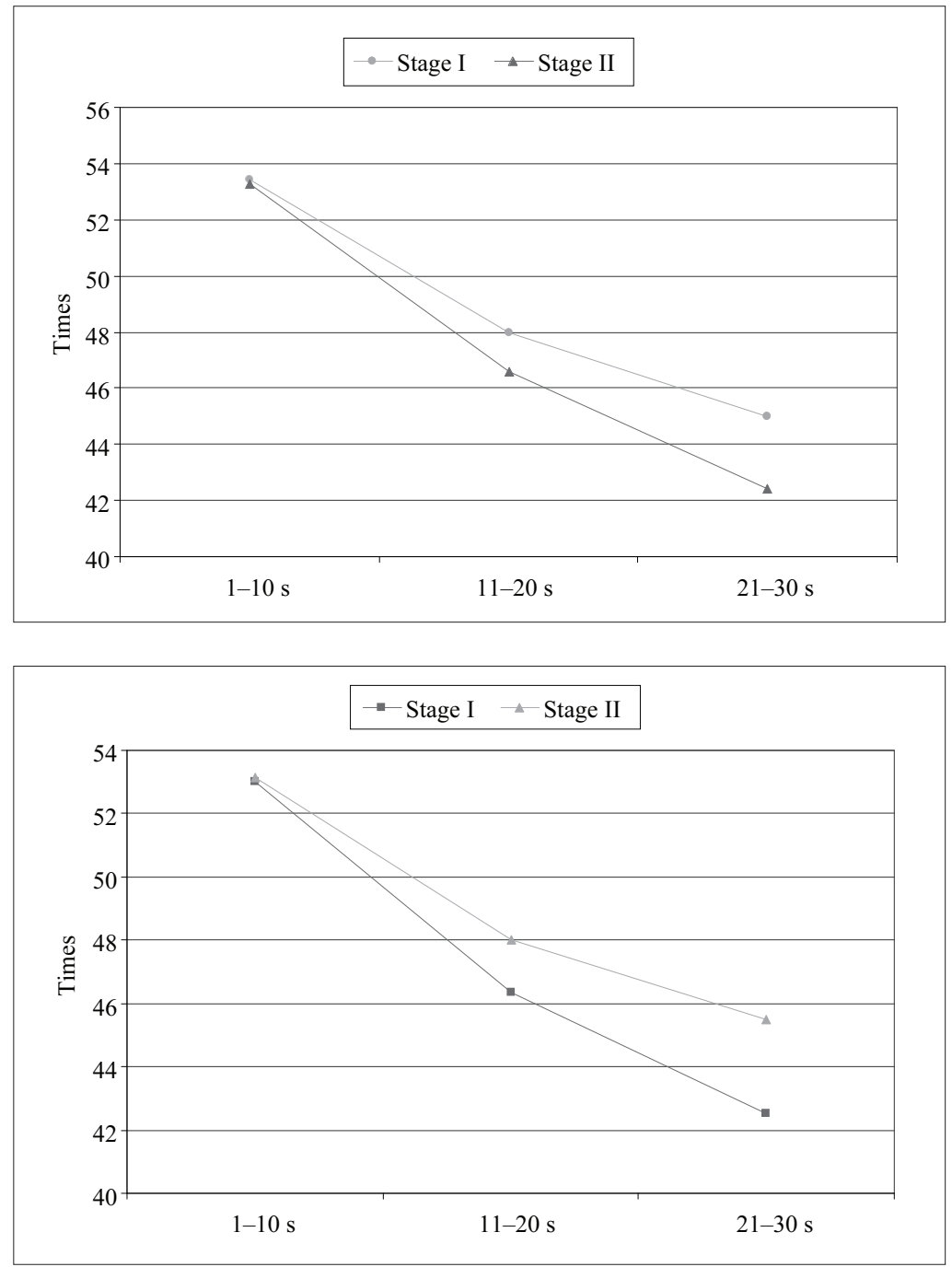
indices of complex psychomotor reaction for boys in the second study were higher compared to the first study $(\mathrm{p}<0.05)$. The girls' indices of complex psychomotor reaction were higher when the task was performed with the right hand ( $\mathrm{p}<0.05)$, but for boys the complex psychomotor reaction reactions did not differ when the task was performed with the right or the left hands.

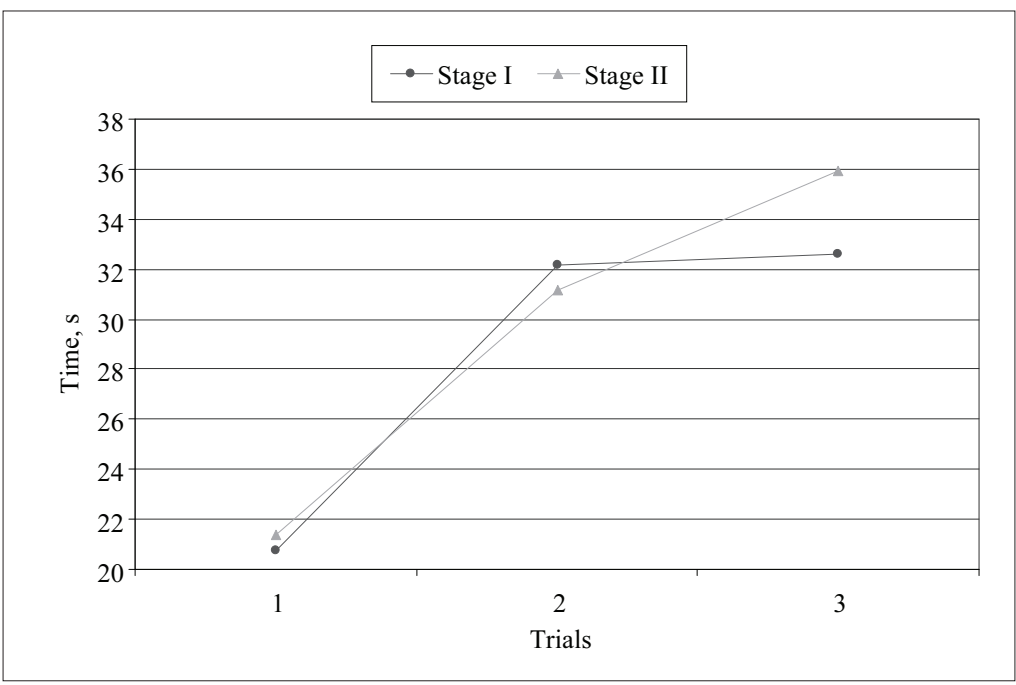

Figure 3. Indices of standing on the front foot of one leg for girls

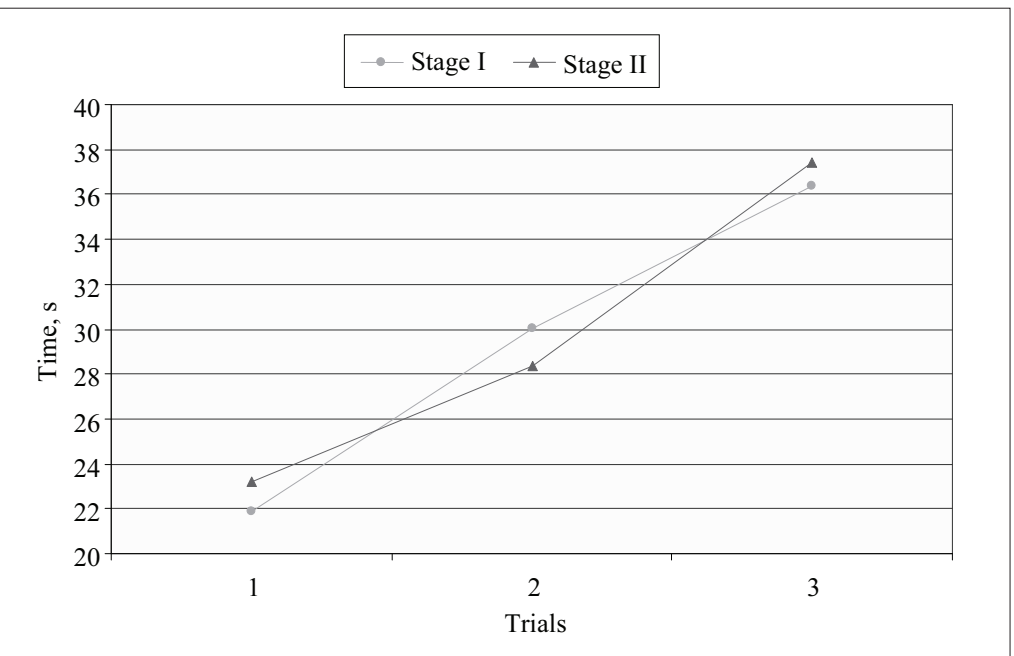

Figure 4. Indices of standing on the front foot of one leg for boys

Table 6. Changes in the indices of psychomotor reactions for boys and girls in junior group of dancers

\begin{tabular}{|c|c|c|c|c|c|c|c|c|c|}
\hline \multirow{3}{*}{ 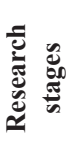 } & \multirow{3}{*}{$\stackrel{\mathscr{E}}{:}$} & \multicolumn{4}{|c|}{ Girls } & \multicolumn{4}{|c|}{ Boys } \\
\hline & & \multicolumn{2}{|c|}{ Simple reaction time, $\mathrm{ms}$} & \multicolumn{2}{|c|}{ Complex reaction time, $\mathrm{ms}$} & \multicolumn{2}{|c|}{ Simple reaction time, $\mathrm{ms}$} & \multicolumn{2}{|c|}{ Complex reaction time, $\mathrm{ms}$} \\
\hline & & Left hand & Right hand & Left hand & Right hand & Left hand & Right hand & Left hand & Right hand \\
\hline \multirow{4}{*}{ I } & $\bar{x}$ & 305.33 & 303.05 & 325.52 & 283.71 & 226.44 & 243.56 & 287.00 & 291.11 \\
\hline & $\pm \mathrm{SD}$ & 42.27 & 30.17 & 27.01 & 37.87 & 35.75 & 16.25 & 45.72 & 31.79 \\
\hline & Min & 244.00 & 268.00 & 280.00 & 255.00 & 182.00 & 225.00 & 234.00 & 258.00 \\
\hline & Max & 360.00 & 341.00 & 342.00 & 359.00 & 261.00 & 261.00 & 291.00 & 328.00 \\
\hline \multirow{5}{*}{ II } & $\bar{x}$ & 267.57 & 255.57 & 309.86 & 259.57 & 194.33 & 194.67 & 243.33 & 243.67 \\
\hline & $\pm \mathrm{SD}$ & 53.89 & 48.40 & 30.29 & 28.45 & 27.63 & 30.52 & 35.85 & 9.31 \\
\hline & Min & 218.00 & 191.00 & 268.00 & 229.00 & 161.00 & 159.00 & 199.00 & 232.00 \\
\hline & Max & 337.00 & 298.00 & 340.00 & 311.00 & 222.00 & 227.00 & 277.00 & 252.00 \\
\hline & $\mathrm{p}$ & $<0.05$ & $<0.05$ & $>0.05$ & $>0.05$ & $<0.05$ & $<0.05$ & $<0.05$ & $<0.05$ \\
\hline
\end{tabular}


Figure 5. Changes in the height of jumps for girls performing a series of 20 jumps

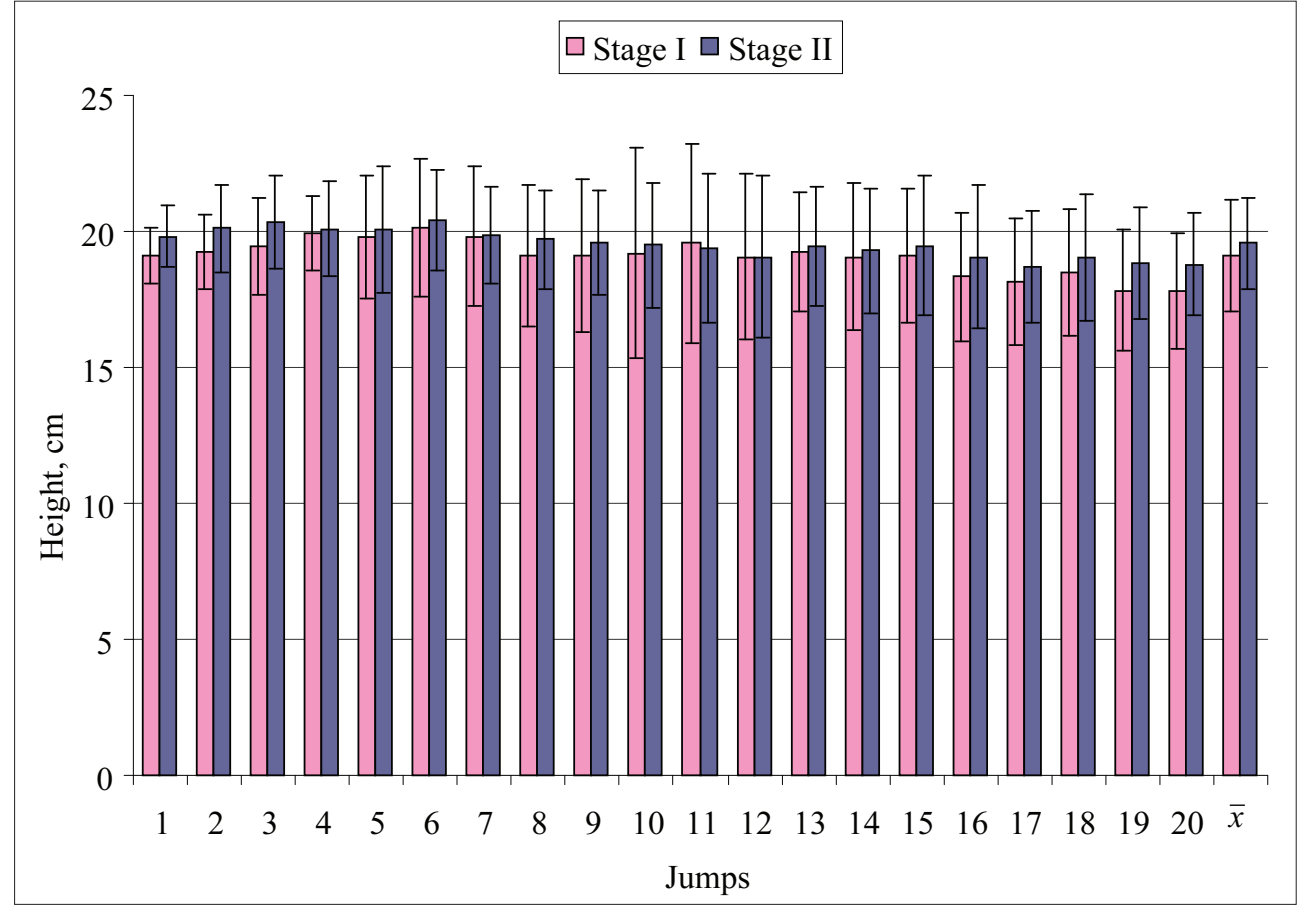

Figure 6. Changes in the height of jumps for boys performing a series of 20 jumps

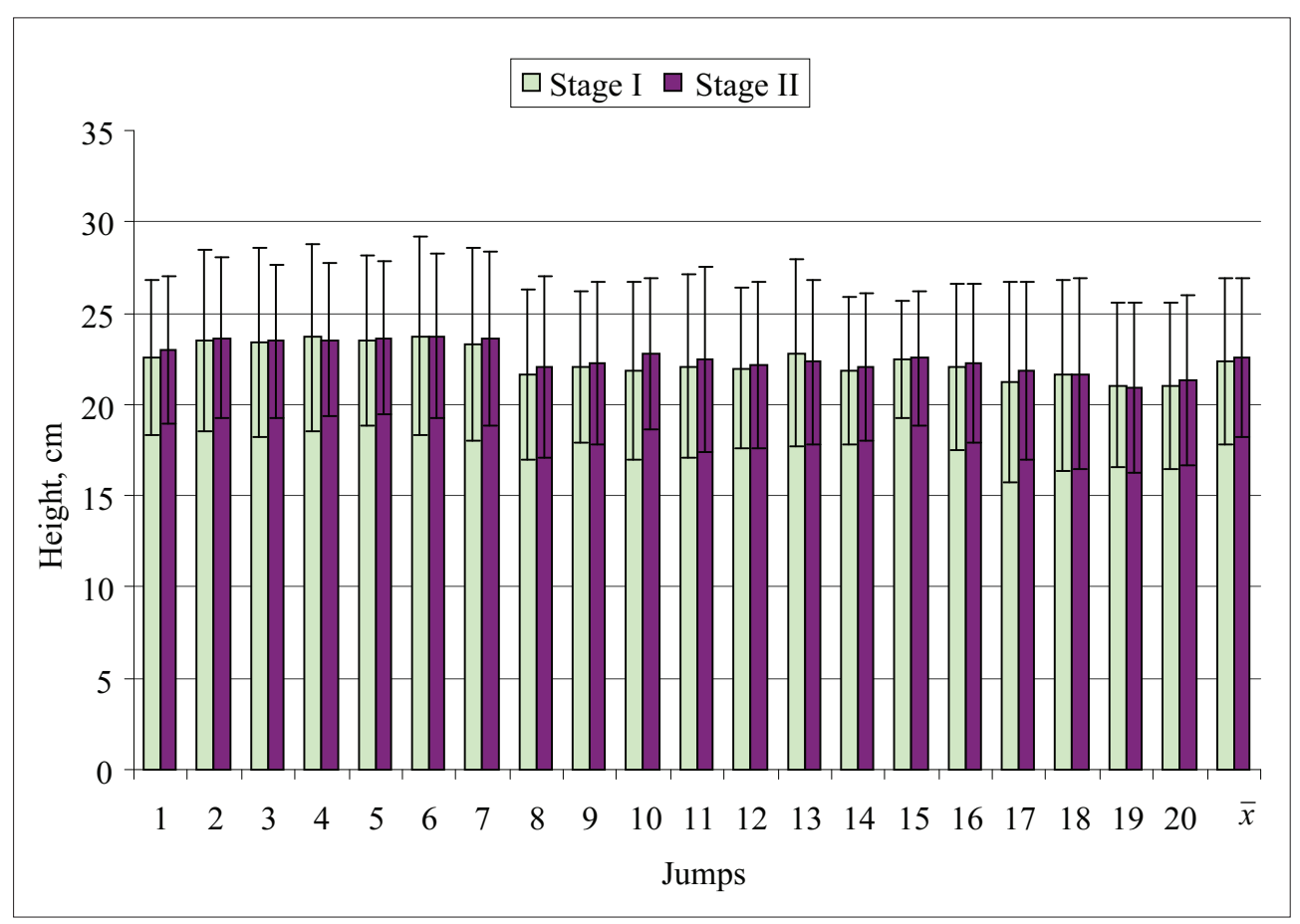

\section{DISCUSSION}

Summing up the process of training junior dancers in sports dancing, we can distinguish the following essential things:

- The greatest attention was paid to teaching elements of dancing techniques and combining them into the whole.

- Dancing technique was taught and improved performing dancing exercises individually without music and with music and then harmonizing with the partner and the partner's movements.

- In the pre-competition cycles the contest program or parts of it are performed modeling the conditions of a competition.

- Practice sessions of athletic training were not conducted. No physical exercises for the development of motor skills were performed during the dancing practice sessions. 
Training young sports dancers much attention should be paid to athletic training (Kostić et al., 2003; Карпенко, Сивицкий, 2009; Климова, 2009; Радионов, 2011). In practice, dancers develop their athletic fitness independently, and not in the practice sessions with a coach. Research shows that athletic fitness of young dancers improves more rapidly when dancing practice sessions include athletic training or physical exercises for the development of motor skills (Радионов, 2011).

The speed of leg movements of boys and girls performing the test "Frequency of steps running on the spot during $10 \mathrm{~s}$ " matched the level of persons engaged in sports (Skernevičius et al., 2004). Both boys and girls produced higher indices of step frequency running for $10 \mathrm{~s}$ then adult D Class male and female dancers (Ušpurienè, Čepulènas, 2011). The speed of hand movements of boys and girls matched the average level of 13-14-year-old schoolchildren (Eurofit, 1993). Changes in the frequency of fine movements of the hand showed that the nervous system of female and male junior dancers is not capable of maintaining constant maximal frequency of fine movements. We believe that those indices are very important for dancers as they show the dancers' speed of spread of nervous impulses and the ability of muscles to adopt impulses (Dadelienè, 2008).

The results of the test "Sit up Lie down during $30 \mathrm{~s}$ " of junior dancers matched the girls' average level and the boys' high level of physical fitness of children of the same age according to the scale of physical fitness in Eurofit (1993). Flexibility indicators for both boys and girls according to the scale of B. L. Johnson, J. K. Nelson (1986) were rather high. The girls' duration indicator standing on the front of one leg (static balance) in the first study was $32.63 \pm 14.69 \mathrm{~s}$, and in the second one $35.96 \pm 11.28 \mathrm{~s}$. The balance indices of female adult $\mathrm{D}$ class dancers according to this test were from $44.43 \pm 9.57 \mathrm{~s}$ to $56.43 \pm 18.85 \mathrm{~s}$ (Ušpurienè, Čepulènas, 2011). The boys' duration indicator standing on the front of one leg during the second study was longer and it reached $37.40 \pm 19.36 \mathrm{~s}$ the relative indices of male adult $\mathrm{D}$ class dancers were from $41.43 \pm 5.19 \mathrm{~s}$ to $48.86 \pm 18.25 \mathrm{~s}$ (Ušpurienè, Čepulėnas, 2011).

In sports dancing, body balance during the whole dance is of great importance (Czabański, 2000). The ability to maintain static balance helps to keep balance in the required positions, and keeping dynamic balance helps to perform various movements and actions under the influence of external powers (Dornowski, Zabrocka, 2008). The results of the jump with hand movements show the power of single leg muscle contraction (Skernevičius et al., 2004). The indices of girls' jump with hand movements corresponded to the average level of junior dancers according to A. Mero et al. (1992) scale. For boys the level was high. Dancing practice sessions had a remarkable positive effect on the psychomotor domain of boys and girls, the indices of simple and complex psychomotor reactions improved ( $p<0.05)$. It is worth noting that that the indices of simple and complex psychomotor reactions of junior boys and girls were lower than those of adult D class male and female dancers (Ušpurienè, Čepulènas, 2011). Psychomotor abilities are very important components of athletic fitness in sports dancing (Czabański, 2000).

Summing up the research findings we suggest that specialized dancing practice sessions did not have greater effect on the improvement of dancers' athletic fitness, but we could observe a tendency of improvement of some athletic fitness elements. The junior dancers' indices of speed, flexibility, strength endurance and explosive strength were adequate to those of boys and girls of the same age group and complied with the average or high level standards.

\section{CONCLUSIONS AND PERSPECTIVES}

- The indices of athletic fitness of junior sports dancers did not change much in the research period. Loads of technical and special training did not affect the changes in dancers' motor skills.

- Athletic fitness is a significant component of junior sports dancers' sports fitness, and the improvement of athletic fitness indices requires inclusion of athletic training into the programs of training sports dancers, or regular practice sessions in sports dancing should be supplemented with physical exercises for the development of motor skills.

Acknowledgments. We would like to thank the coach Sergej Jefimenka for allowing investigating dancers in his group. 


\section{REFERENCES}

Amžiaus apribojimai. (2009). [2010 1 20]. Internet link: http://www.dancesport.lt/nariams/.

Czabański, B. (2000). Kształcenie psychomotoryczne. Wrocław: AWF.

Dadelienè, R. (2008). Kineziologija: monografija. Vilnius: LSIC.

Dornowski, M., Zabrocka, A. (2008). Static and Dynamic Body Balance Maintenance Ability in Young Dance Sport Atletes on the Beginning Stage of Training. World Congress of Performance Anglysis of Sport VIII. Book of Proceedings. Magdeburg. (pp. 577-581).

Eurofitas. (1993). Fizinio pajègumo testai ir metodika. Parengè V. Volbekienè. Vilnius: LSIC.

Faina, M., Bria, S. (2000). Is dancesport a leisure / wellness activity and / or sport? [21 09 2009]. Internet link: http://_www.idsf.net/documents/dancesport_a sport.pdf.

Fostiak, D. (1996). Koordynacja ruchowa u zawodników gimnastyki artystycznej, tyżwiarstwa figurowego $i$ sportowego tańca towarzyskiego. Wydawnictwo Uczelniane AWF w Gdansku.

Haight, H. (1998). Morphologic, physiologic and functional interactions in elite female ballet dancers. Medical Problems of Performing Artists, 13 (1), 4-13.

Johnson, B. L., Nelson, J. K. (1986). Practical Measurements for Evaluation in Physical Education. United States of America.

Kavaliauskas, G. (2004). Šokio ABC. Kaunas: LKKA.

Kostić, R., Miletić, D., Jocić, D., Uzunović, S. (2003). The Influence of Dance Structures on the Motor Abilities of Preschool Children. [2009 12 02]. Internet link: http:// www.facta.junis.ni.ac.rs/pe/pe2002/pe2002-08.pdf.

Kvalifikaciniu klasiu nuostatai. (2009). [2010 12 03]. Internet link: http://www.dancesport.lt/nariams/.

Mero, A., Komi, P., Gregor, R. (1992). Biomechanics of sprint running: A review. Sports Medicine, 13, 376-392. Miletić, D. (1999). Factors of successfulness with folk dances. In P. Parisi, F. Pigozzi, G. Prinzi (Eds.), Fourth ECSS Proceedings Book. Rome, Italy. P. 374.

Pilewska, W. (2003). Sprawność fizyczna i cechy budowy somatycznej jako podstawa modelowych charakterystyk zawodniczek $i$ zawodników $w$ tańcu sportowym: praca doktorska. AWFiS Gdańsk.

Skernevičius, J., Raslanas, A., Dadelienè, R. (2004). Sporto mokslo tyrimu metodologija. Vilnius: LSIC.

Skurvydas, A., Mamkus, G. (Parenge). (1990). Sportininku perspektyvumo ivertinimas, remiantis raumenu kompozicija: metodinès rekomendacijos. Vilnius.

Sporto terminu žodynas. (2002). Parengè S. Stonkus. 2-as pat. ir pap. leidimas. Kaunas: LKKA. P. 411.

Starosta, W. (2003). Motoryczne zdolności koordynacyjne (znaczenie, struktura, uwarunkowania, kształtowanie). Warszawa: Instytut Sportu w Warszawie.
The Revised Technique of Latin-American Dancing ISTD. (1983). London: Lithoflow LTD.

Torrents, C., Castaňer, M., Anguera, M. T. (2011). Dancing with complexity: Observation of emergent patterns in dance improvisation. Ugdymas. Küno kultūra. Sportas, 1 (80), 76-82.

Ušpurienė, A. B., Čepulènas, A. (2011). D klasès sportinių šokių šokejju fizinio parengtumo rodikliai ir jų kaita per metinius rengimo ciklus. Sporto mokslas, 1 (63), 50-56.

Карпенко, Л. А., Сивицкий, В. А. (2009). Базовая подготовка в спортивных танцах на паркете. Учёные записки, 5 (51), 36-40.

Климова, М. В. (2009). Содержание и методика физической подготовки юных таниоров (на примере эстрадно сиенического танца): автореферат диссертации. Белгород: Белгородский государственный университет.

Михайлов, И. А. (1999). Использование упражнений в технической подготовке спортсменов-танцоров. В. И. А. Михайлов, Н. А. Коваленко, Спортивные танць: бюллетень. Проблемь управления, информачионного обеспечения и преподования в спортивных танцах. РГАРК. паб. Спорт. танцов. Москва. С. 26-43.

Пискунова, Л. В. (2004). Упражнения на растяжку в спортивно-технической подготовке спортсменовтанцоров. В. Л. В. Пискунова, Материальг 8-й Всерос. науч.-метод. конф. по проблемам развития танцевальных видов спорта. Москва, 2-6 февр. (сc. 39-41.)

Радионов, М. В. (2011). Физическая подготовленность юных спортсменов-танцоров как средство повышения спортивного результата. Теория $u$ практика физической культуры, 4, 58-61.

Репникова, Е. А. (2004). Применение статодинамических упражнений в системе оздоровительной физической культуры. В. Е. А. Репникова, Спортивные танцыь: бюлетень. Материаль VIII Всерос. науч.-метод. конф. по проблемам развития танцевальных видов спорта. Москва, 2-6 февр. ч. ІІ. (cс. 17-18).

Рубштейн, Н. (2005). V национальньй конгресс тренеров и судей ФТСР. Лекиия по психологии [20 01 2008]. Internet link: http://www.dancesport.ru/ articles/articles_40/art_68.phtml.

Терехова, М. А. (2007). Экспериментальное обоснование методики специальной физической подготовки юных танцоров на этапе начальной специализации. Физическая культура, образование, тренировки, 3, 42-43.

Хемпшир, Г. С. (2000). Венский вальс. Как воспитать чемпиона. В. Г. С. Хемпшир, Современый бальный танец. Москва: Артис. С. 288. 


\title{
JAUNIŲ GRUPĖS SPORTINIŲ ŠOKIŨ ŠOKĖJŲ ATLETINIO PARENGTUMO KAITA PER DEŠIMTIES MÉNESIŲ TRENIRUOTĖS CIKLĄ
}

\author{
Aistė Barbora Ušpurienė, Algirdas Čepulėnas \\ Lietuvos kūno kultūros akademija, Kaunas, Lietuva
}

\begin{abstract}
SANTRAUKA
Tyrimo pagrindimas ir hipotezė. Sportinių šokių šokejjų meistriškumas yra glaudžiai susijęs su jų atletiniu parengtumu, tačiau nèra plačiai ištyrinèti jaunių grupès šokèjų atletinio parengtumo rodiklių kaitos ypatumai šokant sportinius šokius. Tyrimu siekiama patikrinti hipotezę, kad treniruojantis turètu gerèti jauniu grupès sportinių šokiu šokejjų atletinis parengtumas. kaitai.

Tikslas: ištirti sportinių šokių pratybų poveiki jaunių grupės sportinių šokių šokejjų atletinio parengtumo rodiklių

Metodai. Buvo tiriama 14 jaunių grupès šokèjų: 7 mergaitės ir 7 berniukai. Šokejjai testuoti du kartus: $2010 \mathrm{~m}$. sausio ir lapkričio mėnesiais. Šokių pratybos vyko tris kartus per savaitę. Nustatyti šie atletinio parengtumo rodikliai: rankų plaštakų jèga; smulkių rankos judesių dažnis; kojų judesių dažnis bègant vietoje $10 \mathrm{~s}$; rankos judesiu greitumas atliekant 25 judesių ciklus; statinè pusiausvyra; liemens lankstumas; pilvo raumenų dinaminè jègos ištvermè; koju staigioji jëga ir greitumo jèga; staigiosios jègos ištvermé; paprastoji ir sudètingoji psichomotorinè reakcija i šviesos dirgikli.

Rezultatai. Šokiu pratybos turèjo didelị teigiamą poveiki šokèjų mergaičių ir berniukų psichomotorikai pagerèjo mergaičiu paprastoji psichomotorinè reakcija $(\mathrm{p}<0,05)$, berniuku - paprastoji ir sudètingoji $(\mathrm{p}<0,05)$. Jaunių grupès sportinių šokių šokejų atletinio parengtumo rodikliai tiriamuoju laikotarpiu mažai kito.

Aptarimas ir išvados. Specializuotos sportinių šokių pratybos didesnio poveikio šokejų atletinio parengtumo gerèjimui nepadarè, tačiau pastebėta atletinio parengtumo gerèjimo tendencija. Norint paspartinti šokẻjų atletinio parengtumo gerejjimą, reikètu i jauniu grupès sportinių šokių šokèjų treniravimo programas ịtraukti fizinius pratimus atletiniam parengtumui tobulinti.
\end{abstract}

Raktažodžiai: sportiniai šokiai, atletinis rengimas, judamieji gebejjimai, šokių pratybos, atletinis parengtumas, treniravimas. 